\title{
PENGARUH UKURAN PARTIKEL AMPAS SAGU DALAM PRODUKSI PIGMEN ANGKAK MENGGUNAKAN Monascus purpureus ${ }^{1}$
}

\author{
Alfi Asben dan Deivy Andhika Permata \\ Program Studi Teknologi Hasil Pertanian, Fakultas Teknologi Pertanian \\ Universitas Andalas, Limau Manis, Padang, 25163 \\ E-mail: alfi_asben@yahoo.com
}

\begin{abstract}
Angka pigment is one of food colorants that safe to used. It can be produced by subtrate that contain of sago hampas. The objective of the research was to get the appropriate of sago hampas particle size to produce the angkak pigment. The steps to produce of angkak pigment were (a) Preparation of raw materials (sago hampas and rice flour substrate with comparison $1: 1(12.5: 12.5)$. This research used three treatments of sago hampas particle size (40-60 mesh, 60-80 mesh, and >80 mesh) with 3 replications, (b) Preparation of Monascus purpureus culture, (c) Solid state fermentation to produce angkak pigment using $M$. purpureus. The results of the research showed that the substrate with hampas sago particle size 40-60 mesh produced the best angkak pigment. The angkak pigment obtain the highest color intensity on $\lambda 400 \mathrm{~nm}, \lambda 470 \mathrm{~nm}, \lambda 500 \mathrm{~nm}$ were 6004,5110 and 3650 respectively, the highest used starch, antioxidant, toxicity, lovastatin and spore of M. purpureus were $11.07 \%, 45.95 \%$, $1719.86\left(\mathrm{LC}_{50}\right), 79 \mathrm{ppm}$, and $3.4 \times 10^{3} \mathrm{CPU} / \mathrm{g}$ respectively.

Keywords-angkak pigment; monascus purpureus; sago hampas; particle size
\end{abstract}

\section{PENDAHULUAN}

Pada awalnya pewarna makanan menggunakan pewarna alami yang berasal dari tanaman, hewan, atau mineral. Harga pewarna alami yang cenderung lebih mahal dan umumnya tidak stabil terhadap pengaruh cahaya dan panas sehingga sering tidak cocok digunakan dalam industri makanan. Hal ini menyebabkan penggunaan zat warna sintetik semakin meluas. Salah satu pewarna alami yang dapat digunakan dan dikembangkan yaitu angkak. Secara tradisional, pembuatan angkak umumnya dilakukan dengan menggunakan beras sebagai substrat melalui sistem fermentasi padat oleh Monascus purpureus (M. purpureus). Selain media beras, ada beberapa jenis umbi dan bahan lain yang memiliki kandungan pati cukup tinggi yang dapat digunakan sebagai substrat bagi pertumbuhan M. purpureus untuk menghasilkan pigmen angkak. Monascus purpureus merupakan kapang utama yang ada pada angkak (Indrawati, Tisnadjaja, Ismawatie, 2010). Perbandingan karbon dan nitrogen dan juga kemungkinan adanya jenis karbohidrat yang berbeda di dalam media diduga menyebabkan intensitas warna yang didapat juga berbeda (Kusumawati, Suranto, Setyaningsih, 2005). Secara tradisional angkak diproduksi menggunakan beras sebagai substrat melalui sistem fermentasi padat. Namun, saat ini angkak juga banyak diproduksi dari berbagai substrat, seperti limbah industri makanan, diantaranya dedak padi, ampas tahu dan onggok (Kusumawati, et al 2005). Pigmen angkak juga dapat dihasilkan dari ampas sagu (Asben dan Kasim, 2015). Pertumbuhan pada substrat padat dipengaruhi oleh beberapa faktor lingkungan antara lain kelembaban, aerasi, $\mathrm{pH}$, suhu dan kualitas inokulum (Lotong and Suwanarit, 1990; Schmitt and Blanc, 2001 cit Timotius, 2004).

Warna merah angkak sangat potensial sebagai pengganti warna merah sintetik yang saat ini penggunaannya sangat luas pada berbagai produk makanan. Monascus purpureus menghasilkan enam jenis pigmen, yaitu 2 jenis pigmen orange (monascorubrin dan rubropunctatin), 2 jenis pigmen kuning (ankaflavin dan monascin), 2 jenis pigmen merah (monascorubramin dan rubropunctamin) (Andarwulan dan Faradilla, 2012). Permana et al., (2003) menyatakan bahwa pada proses fermentasi angkak, pigmen-pigmen tersebut terbentuk berurutan, yaitu pada awal fermentasi hypa Monascus purpureus berwarna kuning, kemudian bagian ascomata menghasilkan warna pigmen merah. Pada awal pembentukan pigmen, warna yang pertama kali terbentuk adalah warna putih kemudian berkembang

\footnotetext{
${ }^{1}$ Telah diseminarkan Seminar Nasional Politani Payakumbuh 21 September 2016
} 
dari pigmen kuning menjadi pigmen merah. Perubahan warna ini disebabkan adanya reaksi dengan asam amino sehingga terbentuk warna merah (Timotius, 2004).

Pada proses pembuatan angkak dalam penelitian ini substrat yang digunakan adalah ampas sagu yang ditambah tepung beras. Ampas sagu dikenal sebagai bahan ligneselulosa yang mengandung pati, yang terdiri dari serat-serat empulur diperoleh dari hasil pemarutan/pemerasan isi batang sagu. Hal inilah yang menyebabkan ampas sagu berpotensi menimbulkan dampak pencemaran lingkungan. Pemanfaatan ampas sagu perlu dimaksimalkan agar pencemaran lingkungan oleh ampas sagu dapat diminimalkan.

Ampas sagu (Metroxylon Sago) merupakan limbah padat hasil pertanian pengolahan pati sagu yang tersedia cukup banyak sepanjang tahun, murah dan mudah didapat. Ampas sagu umumnya berukuran dari 20-60 mesh, hasil pengolahan industri menengah. Dalam pengolahan empulur sagu diperoleh 18,5\% pati sagu dan 81,5\% berupa ampas sagu (Kiat, 2006). Menurut Asben et al. (2012), persentase kandungan bahan utama ampas sagu, yaitu hemiselulosa $14 \%$, selulosa $21 \%$, lemak $2 \%$, protein kasar $1 \%$, lignin $6 \%$, pati $51 \%$, dan lainnya $5 \%$. Kandungan protein ampas sagu yang rendah, menyebabkan perlunya penambahan bahan pangan sebagai sumber protein, dimana sedapat mungkin dari bahan yang juga mengandung pati yang tinggi. Tepung beras merupakan salah satu produk olahan beras yang memiliki kandungan protein yang cukup tinggi, yaitu sebesar 7,00 gr per 100 gram bahan (Direktorat Gizi Departemen Kesehatan RI, 1996). Kandungan nutrisi yang cukup pada substrat terutama karbon dan nitrogen akan menunjang pertumbuhan M. purpureus selama proses fermentasi.

Fermentasi subtsrat padat (solid state fermentation) adalah fermentasi yang melibatkan mikroorganisme pada substrat padat lembab dimana tidak ada air yang mengalir bebas. Pada fermentasi substrat padat perlu diperhatikan beberapa hal untuk meningkatkan produksinya, salah satunya ukuran parikel. Pada ampas sagu untuk produksi pigmen alami, diperlukan ukuran partikel yang baik atau sesuai, ukuran partikel akan mempengaruhi aerasi pada substrat padat dan pada akhirnya mempengaruhi pertumbuhan dari kapang. Pertumbuhan dan metabolisme Monascus purpureus dipengaruhi oleh aerasi yang diberikan selama pertumbuhan berlangsung. Produksi metabolit sekunder sangat memerlukan kondisi aerasi yang baik. Aerasi diperlukan untuk menjaga persediaan oksigen untuk pertumbuhan maupun untuk produksi metabolit sekunder. Menurut Hajjaj, Blanc, Groussac, Goma, Uribelarrea, Loubiere, 1999a cit Timotius (2004), produksi metabolit sekunder sangat memerlukan aerasi yang baik. Jika oksigen dalam keadaan terbatas maka produksi etanol akan meningkat sedangkan produksi biomassa dan pigmen menurun (Timotius, 2004).

Inokulum yang baik adalah inokulum yang banyak mengandung askospora atau askomata (Timotius, 2004). Selain itu, penambahan sumber-sumber karbon (glukosa, maltosa, atau etanol) dan $0,1-0,5 \%$ sumber nitrogen (pepton dan amonium nitrat) pada substrat, dapat meningkatkan kemampuan inokulum dalam memproduksi pigmen (Andarwulan dan Faradila, 2012). Hasil fermentasi terutama tergantung pada jenis bahan pangan (substrat), jenis mikroba dan kondisi di sekelilingnya yang mempengaruhi pertumbuhan dan metabolism mikroba tersebut (Uhi, 2007). Kondisi optimal untuk proses pembentukan pigmen adalah pada $\mathrm{pH} 6$, suhu $30-35^{\circ} \mathrm{C}$, dan kelembaban $56 \%$.

Berdasarkan penjelasan di atas dilakukan penelitian pembuatan angkak dengan memanfaatkan ampas sagu dengan mempertimbangkan variasi ukuran partikel ampas sagu untuk menghasilkan pigmen yang diinginkan. Penelitian ini bertujuan untuk mendapatkan ukuran partikel ampas sagu yang tepat untuk menghasilkan pigmen angkak.

\section{METODOLOGI PENELITIAN}

\section{A. Bahan dan Alat}

Bahan yang akan digunakan dalam penelitian ini antara lain tepung beras, ampas sagu (Desa Subarang, Kota Pariaman), biakan murni Monascus purpureus (IPBCC, IPB Bogor), media Potato Dextrose Agar (PDA), garam fisiologis, aquades steril, starter, larutan glukosa, $\mathrm{HCL} 30 \%, \mathrm{NaOH} 4 \mathrm{~N}$, Luff schrool, KI $30 \%, \mathrm{H}_{2} \mathrm{SO}_{4} 25 \%$, indikator kanji $0,5 \%, \mathrm{Na}_{2} \mathrm{~S}_{2} \mathrm{O}_{3}$ (thio) $0,1 \mathrm{~N}$, methanol, DPPH, larva udang, air laut, asetonitril, asam fosfat, asam asetat pekat.

Peralatan yang digunakan adalah enchase, jarum ose, test tube, petridish, Erlenmeyer $250 \mathrm{ml}$, aluminium foil, timbangan analitik, gelas ukur, pengaduk, incubator, hot plate, spektofotometer, $\mathrm{pH}$ meter, kertas saring, oven, gelas piala, autoclave, haemocytometer, mikroskop, enchase, pendingin tegak, sentrifuse. 


\section{B. Metode Penelitian}

Penelitian ini menggunakan metode penelitian eksploratif. Penelitian produksi pigmen angkak dari substrat ampas sagu dan tepung beras dilakukan dengan tahapan sebagai berikut, yaitu (i) persiapan bahan baku (substrat ampas sagu dan tepung beras) dengan perbandingan ampas sagu dan tepung beras $1: 1(12,5: 12,5)$. Perlakuan penelitian yaitu ukuran partikel ampas sagu dengan 3 perlakuan yaitu :A. 40-60 mesh, B. 60-80 mesh, dan C. $>80$ mesh), (ii) persiapan kultur Monascus purpureus, (iii) fermentasi angkak dengan system fermentasi padat. Penelitian dilakukan 3 kali ulangan. Data ditampilkan dalam bentuk tabulasi hasil hitung statistik rata-rata

\section{Prosedur Penelitian}

\section{Persiapan Bahan Baku Sebagai Substrat Fermentasi}

Persiapan bahan ampas sagu; Ampas sagu dikeringkan sampai kadar air 10-12\%. Ampas sagu dikecilkan dan dihaluskan menggunakan blender kemudian di ayak sesuai ukuran partikel yang dikehendaki, yaitu 40-60 mesh, 60-80 mesh dan $>80$ mesh.

\section{Persiapan Kultur (Asben dan Kasim, 2015)}

Kultur yang akan dipergunakan dipersiapkan sebagai berikut: Siapkan biakan murni Monascus purpureus ke agar miring PDA. Biakan murni diinkubasi pada suhu $28-30^{\circ} \mathrm{C}$. Biakan siap dipakai setelah berumur 21 hari. Selanjutnya, lepaskan askospora maupun konidia yang ada pada permukaan agar menggunakan lup inokulasi dengan cara, memasukkan $5 \mathrm{ml}$ aquades steril ke dalam 1 test tube agar miring dan digerus menggunakan jarum ose sehingga askospora dan konidia terlepas. Selanjutnya, hitung spora dengan menggunakan haemocytometer.

\section{Fermentasi Ampas Sagu dan Tepung Beras Sebagai Media Padat (Asben dan Kasim, 2015 modifikasi)}

Erlenmeyer $250 \mathrm{ml}$ steril disiapkan sebanyak 9 buah. Dimasukkan ampas sagu dengan variasi 3 ukuran partikel; A (40-60 mesh), B (60-80 mesh), C (>80 mesh) dan tepung beras, dengan perbandingan ampas sagu : tepung beras $1: 1$ (12,5:12,5 gram). Selanjutnya ditambahkan larutan glukosa 2,5\% sampai kadar air substrat $\pm 50 \%$, ukur $\mathrm{pH}$ dan kandungan pati substrat awal. Sterilisasi dengan autoklaf $121^{\circ} \mathrm{C}$ selama 15 menit. Dimasukkan inokulum yang telah dihasilkan sebanyak $10 \%$ $(4,5 \mathrm{ml})$. Diaduk-aduk substrat hingga homogen. Kemudian inkubasi pada suhu ruang $28-30^{\circ} \mathrm{C}$ selama 21 hari. Hasil fermentasi dikeringkan selama kurang lebih 72 jam pada kondisi yang sama dalam cainet dryer, yaitu pada suhu $40-45^{\circ} \mathrm{C}$. Tentukan kadar air pigmen angkak setelah jadi serbuk hingga $\pm 7 \%$. Produk angkak siap dianalisis.

\section{Pengamatan}

Pengamatan yang dilakukan pada bahan baku atau substrat, yaitu kadar air (AOAC, 2005), pH, dan kadar pati awal (metode luff Scrooll); jumlah spora yang digunakan sebagai inokulum dengan haemocytometer (Nufus, 2013); pada produk angkak yaitu pH, pati, kadar air (AOAC, 2005), analisis pigmen warna (metode spektrofometri dalam Kasim et al., 2005), analisis mikroorganisme (metode SPC dan haemocytometer), uji antioksidan (metode DPPH; Anggraini, 2013) dan uji toksisitas (Hernindya et al., 2014). Pengujian Lovastatin dilakukan produk terbaik (metoda HPLC).

\section{HASIL DAN PEMBAHASAN}

\section{A. Bahan Baku Ampas Sagu}

Hasil analisis bahan baku ampas sagu dan juga dalam bentuk substrak yang telah dicampur dengan tepung beras baik yang belum distrilisasi maupun yang telah disterilisasi dapat dilihat pada Tabel 1. Pada Tabel 1, pH substart ampas sagu sebelum disterilisasi berkisar 5,87-6,17, setelah disterilisasi $\mathrm{pH}$ sedikit berubah dimana $\mathrm{pH}$ tertinggi yaitu pada ukuran partikel 40-60 mesh yaitu 5,63 dan yang terendah adalah ukuran partikel $>80$ mesh yaitu 5,13 . Secara keseluruhan $\mathrm{pH}$ substrat yang digunakan masih baik mendukung fermentasi. Timotius (2004) menyatakan kondisi optimal proses pembentukan pigmen adalah pada $\mathrm{pH} 6$, suhu $30-35^{\circ} \mathrm{C}$, dan kelembaban $56 \%$. 
Tabel 1. Variasi pH, Kandungan Pati dan Kadar Air dari Substrat Ampas sagu

\begin{tabular}{|c|c|c|c|c|}
\hline $\begin{array}{c}\text { Perlakuan Ampas Sagu } \\
\text { (mesh) }\end{array}$ & \multicolumn{4}{|c|}{ Substrat Awal } \\
\cline { 2 - 5 } & $\mathbf{p H}$ & $\mathbf{p H}^{*}$ & Pati (\%) & Kadar Air (\%)* \\
\hline $40-60$ & $6,17 \pm 0,153$ & $5,63 \pm 0,058$ & $65,08 \pm 0,962$ & $38,11 \pm 3,736$ \\
\hline $60-80$ & $6,03 \pm 0,153$ & $5,43 \pm 0,116$ & $65,84 \pm 0,431$ & $36,63 \pm 0,978$ \\
\hline$>80$ & $5,87 \pm 0,058$ & $5,13 \pm 0,058$ & $69,18 \pm 6,059$ & $38,81 \pm 0,048$ \\
\hline
\end{tabular}

Keterangan : ${ }^{*}$ setelah sterilisasi

Kandungan pati substrat ampas sagu yang cukup tinggi yaitu berkisar 65,08-69,18\% disebabkan adanya pencampuran ampas sagu dengan tepung beras dengan perbandingan $1: 1$. Kadar pati ampas sagu adalah 51\% (Asben et al, 2012) dan tepung beras sebesar 80\% (Direktorak Gizi, Depkes RI, 1996). Dengan perbandingan $1: 1$ antara ampas sagu dengan tepung beras diperkirakan kadar pati bahan baku secara teoritik adalah 65,5\%. Pada perlakuan partikel ampas sagu lebih besar dari 80 mesh makin banyak bahagian pati sagu yang ikut terbawa dibanding perlakuan patikel 40-60 mesh dimana bagian pati ampas tidak banyak terbawa (ukuran partikel pati sagu kecil dari 80 mesh), sehingga pati pada perlakuan ini terhitung sedikit lebih tinggi.

Kadar air substrat ampas sagu sebelum fermentasi rata-rata adalah 38\%, dimana untuk partikel 60-80 mesh kadar airnya sekitar 36\%. Kadar air pada substrat ini meningkat karena adanya penambahan glukosa 2,5\% sebanyak $20 \mathrm{~mL}$ untuk mencapai kadar air substrat 50\%. Meskipun demikian, kadar air substrat ini sedikit lebih rendah dari kadar air susbrat yang diinginkan (50\%), hal ini disebabkan kadar air dari ampas sagu sekitar 11,20\% (tidak sampai 12\%) dan kadar air tepung beras sekitar $8 \%$, sehingga penambahan glukosa $2,5 \%$ sebanyak $20 \%$ belum sampai pada kadar air substrat yang diharapkan sesuai perhitungan awal.

\section{B. Pigmen Angkak Dari Variasi Ukuran Partikel Ampas Sagu Substrat}

Hasil analisis kadar air dan intesitas warna angkak yang dihasilkan ditampilkan pada Tabel 2. Pigmen angkak yang dihasilkan dari proses fermentasi, dikeringkan dalam cabinet dryer selama 72 jam dimana didapatkan kadar air berkiras 6 - 7\%. Pada kadar air yang relatif sama ini diukur intesitas warna yang dihasilkan pigmen angka. Ada tiga warna utama yang dapat ditimbulkan oleh pigmen pada angkak, yaitu kuning, oranye, dan merah (Ma et al., 2000. Intesitas waran kuning diukur dengan $\lambda 400$ $\mathrm{nm}$, warna orange pada $\lambda 470 \mathrm{~nm}$ dan warna merah pada $\lambda 500 \mathrm{~nm}$. Adapun hasil analisis intesitas warna tersebut disajikan pada Tabel 2.

Tabel 2. Kadar Air dan Intesitas Warna dari Pigmen Angkak dari 3 Ukuran Partikel Ampas Sagu Substrat

\begin{tabular}{|c|c|c|c|c|}
\hline \multirow{2}{*}{$\begin{array}{c}\text { Perlakuan Ampas } \\
\text { Sagu } \\
\text { (mesh) }\end{array}$} & \multirow{2}{*}{ Kadar air (\%) } & \multicolumn{3}{|c|}{$\begin{array}{c}\text { Intensitas warna } \\
\text { Panjang Gelombang (nm) }\end{array}$} \\
\cline { 3 - 5 } & & $\mathbf{4 0 0}$ (kuning) & $\mathbf{4 7 0}$ (orange) & $\mathbf{5 0 0}$ (merah) \\
\hline $40-60$ & $6,99 \pm 0,298$ & $6,004 \pm 0,8674$ & $5,110 \pm 0,9909$ & $3,650 \pm 0,6388$ \\
\hline $60-80$ & $6,82 \pm 0,546$ & $5,787 \pm 1,3336$ & $4,850 \pm 2,1422$ & $3,456 \pm 1,0462$ \\
\hline$>80$ & $7,14 \pm 0,723$ & $4,217 \pm 0,6013$ & $2,821 \pm 0,6847$ & $2,113 \pm 0,5219$ \\
\hline
\end{tabular}

Pada Tabel 2 dapat dilihat bahwa pola intesitas warna sama untuk ketiga variasi ukuran partikel ampas sagu ini dimana intesitas warna kuning paling tinggi diikuti intesitas warna orang dan intensitas warnan merah. Pola ini sama yang dilaporkan oleh Asben dan Kasim (2015), dimana substrat yang digunakan juga ampas sagu. Secara umum pigmen warna utama yang dihasilkan oleh M. purpureus pada fermentasi angkak adalah monaskorubrin (orange) dan monaskoflavin (merah). Pada substart ampas sagu didapatkan pigmen warna kuning lebih tinggi intensitasnya.

Jika dilihat pengaruh ukuran partikel ampas sagu yang digunakan sebagai subtrat terhadap intensitas warna yang dihasilkan pada masig masing panjang gelombang warna (400, 470 dan $500 \mathrm{~nm})$, terlihat bahwa makin kecil ukuran partikel maka makin rendah intesitas warna yang dhasilkan. Hal ini berhubungan dengan hasil metabolisme yang dihasilkan $M$ purpureus, semakin baik pertumbuhan $M$ purpureus maka semakin banyak hasil metabolit yang dihasilkan. Ukuran partikel ampas sagu 40-60 mesh diperkirakan memberikan pengaruh yang baik bagi hipa dan miselium kapang M purpureus untuk 
dapat terus masuk dan mengkonversi nutrisi (pati) yang terdapat pada lapisan dalam susbtsrat karena fermentasi dilakukan dalam bentuk substart padat. Semakin banyak nutrisi yang dimanfaatkan maka makin banyak produk metabolit yang dihasilkan. Pigmen pada angkak merupakan hasil metabolisme sekunder.

Pertumbuhan jamur berfilamen pada medium padat datar, dimulai dengan tumbuh dan berkembangnya hifa pada pemukaan substrat, selanjutnya masuk ke pori-pori antara partikel substrat merupakan. Ukuran partikel yang semakin kecil menyebabkan pori-pori semakin sedikit dan makin menyulitkan hifa untuk tumbuh terus kedalam dan berkembang membentuk miselium dan mengkonversi substrat menjadi produk metabolit. Pori antar partikel yang cukup tersedia akan membantu hifa dalam mengkonsusmsi nutrisi pada substrat dan berkemabng menjadi miselium yang selanjutnya membentuk spora yang lebih banyak. Semakin banyak hifa, meselium dan spora yang terbentuk maka semakin intensitas warna pigment yang dihasilkan M. purpureus.

Pada hasil analisis pati, anti oksidan, uji toksisitas dan kandungan lovastatin angkak yang dihasilkan memperlihatkan bahwa ukuran partikel memberi perbedaan hasil. Hasil analisis ini sejalan dengan Tabel 2. Dimana ukuran partikel yang lebih besar (40-60 mesh) memberikan hasil yang lebih baik. Hasil analis beberapa paremeter ini dapat dilihat pada Tabel 3.

Tabel 3. Kandungan Pati, Anti oksidan, Toksisitas dan Lovastatin Angkak Dari 3 Ukuran Partikel Ampas Sagu Substrat

\begin{tabular}{|c|c|c|c|c|}
\hline $\begin{array}{c}\text { Ampas Sagu } \\
\text { (mesh) }\end{array}$ & $\begin{array}{c}\text { Pati angkak } \\
(\%)\end{array}$ & $\begin{array}{c}\text { Anti oksidan } \\
(\%) *\end{array}$ & Toksisitas $\mathrm{LC}_{50}$ & Lovastatin (ppm) \\
\hline $40-60$ & $54,07 \pm 0,694$ & $45,95 \pm 0,550$ & $1719,86 \pm 588,002$ & $79,00 \pm 1,414$ \\
\hline $60-80$ & $59,69 \pm 2,417$ & $42,25 \pm 4,55$ & $1695,19 \pm 403,249$ & - \\
\hline$>80$ & $63,37 \pm 0,306$ & $35,37 \pm 3,683$ & $1513,99 \pm 338,988$ & - \\
\hline
\end{tabular}

Pada Tabel 3, terlihat kandungan pati terendah yang tersisa pada substrat fermetasi adalah pada substrat dengan ukuran partikel 40-60 mesh yaitu 54,07\%. Bila dilihat dari pati substrat awal (Tabel 1), maka substrat ampas sagu ukuran partikel 40-60 mesh mengalami kehilangan pati yang tertinggi yaitu $11,01 \%$. Demikian juga dengan kandungan anti oksidan dan uji toksisitas memperlihatkan ukuran partikel ampas sagu 40-60 mesh memberikan hasil yang tertinggi yaitu 45,95\%, dan 1719,86 berturutturut. Kapang M. purpureus yang dapat tumbuh lebih banyak dan menembus partikel pori yang lebih besar serta dengan oksigen yang lebih tersedia pada ampas sagu ukuran 40-60 mesh mendorong terbentuknya hasil metabolit yang lebih banyak sehingga dapat mengahsilkan anti oksidanyang tinggi, dan produk yang dihasilkan tidak bersifat toksit. Nilai toksisitas 1719.86 jauh diatas nilai 1000 pada $\mathrm{LC}^{50}$ yang merupakan batas toksisitas dari produk. Fardiaz dan Zakaria (1996) menyatakan kapang $M$. purpureus menghasilkan pigmen yang tidak toksik dan tidak mengganggu sistem kekebalan tubuh. Hasil metabolit berupa pigmen yang tingi dapat menekan kemungkinan adanya bahan toksit pada ampas sagu. Lebih lanjut Yongsmith (1999) menyatakan jamur Monascus memproduksi angkak dengan mengkonversi substrat zat tepung menjadi beberapa metabolit, seperti alkohol, agen antibiotik, antihipertensi, enzim, asam lemak, senyawa aromatik, keton, asam organik, pigmen, dan vitamin. Monascus juga mampu menghasilkan antioksidan, dan asam dimerumat ( Taira et al., 2002; Su et al., 2003).

Hasil analisis lovastatin dilakukan untuk produk dengan intesitas pigmen tertinggi yaitu pada substrat dengan penggunaan ampas sagu 40-60 mesh. Angkak dari substart ampas sagu dapat menghasilkan lovastatin. Lovastatin yang diperoleh pada perlakuan ini adalah $79 \mathrm{ppm}$ (fermentasi 21 hari). Lovastatin atau monakolin adalah komponen bioaktif yang diketahui terdapat di dalam angkak sehingga dapat menurunkan kadar kolesterol dalam darah. Pembentukan lovastatin oleh Monascus purpureus terjadi setelah fase pertumbuhan (Kasim et al., 2006). Diperkirakan waktu fermentasi yang lebih cepat (14 hari) angkak yang dihasilkan mengandung lovastatin yang lebih tinggi. Hasil uji mikrobiologi terhadap M purpureus yang masih hidup setelah dikeringkan 3 hari pada kadar air 6-7\% dengan suhu $40-45^{\circ} \mathrm{C}$ dapat dilihat Pada Tabel 4 . 
Tabel 4. Hasil Uji Mikrobiologi (Spora M. purpureus) Produk Angkak Dari 3Jenis Ukuran Partikel Ampas Sagu Yang Berbeda

\begin{tabular}{|c|c|}
\hline $\begin{array}{c}\text { Perlakuan Ampas Sagu } \\
\text { (mesh) }\end{array}$ & $\begin{array}{c}\text { SPC } \\
\text { (CPU/g) }\end{array}$ \\
\hline $40-60$ & $3.4 \times 10^{3}$ \\
\hline $60-80$ & $5.2 \times 10^{3}$ \\
\hline$>80$ & $3.5 \times 10^{3}$ \\
\hline
\end{tabular}

Dari Tabel 4. Dapat dilihat bahwa setalah pengeringan 3 hari pada suhu $40-45^{\circ} \mathrm{C}$ ternyata masih terdapat spora $M$. purpureus yang masih dapat tumbuh dan berkembang. Perbendaan ukuran partikel tidak memberi perbedaan yang mencolok terhadap jumlah spora $M$. purpureus yang masih tersisa. Masih terdapat rata-rata 3,5 $\times 10^{3}$ spora $M$. purpureus pada produk angkak dari campuran ampas sagu dengan tepung beras. Gambar 1 merupakan proses pembuatan pigmen angkak hasil fermentasi dari ampas sagu yang dicampur dengan tepung beras menggunakan M. Purpureus.

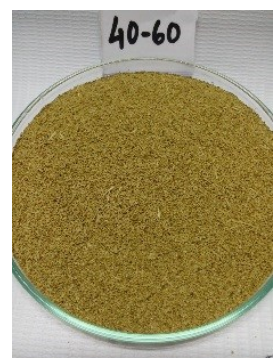

(a)

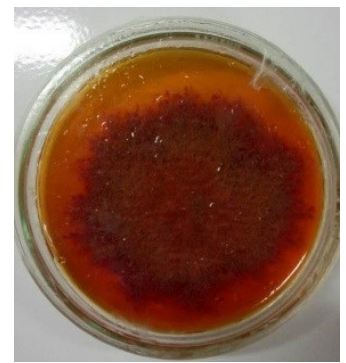

(b)

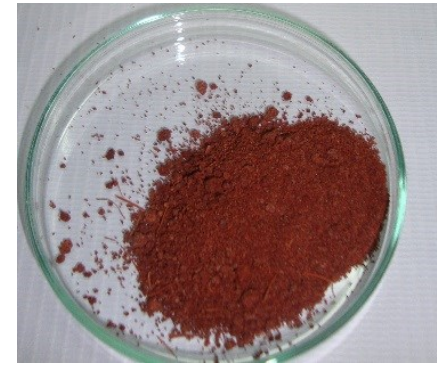

(c)

Gambar 1. Proses pembuatan pigmen angkak dari ampas sagu : (a) ampas sagu ukuran 40-60 mesh, (b) $M$, purpureus, dan (c) angkak dari ampas sagu ukuran 40-60 mesh

\section{KESIMPULAN}

Substrat dengan campuran ampas sagu dengan ukuran partikel 40-60 mesh memberikan hasil terbaik dengan intesitas warna tertinggi yaitu 6.004 ( $\lambda 400 \mathrm{~nm}$, pigmen warna kuning), 5.110 ( $\lambda 470$ $\mathrm{nm}$, pigmen warna orange) dan $3.650(\lambda 500 \mathrm{~nm}$, pigmen warna merah); penggunaan pati tertinggi 11,07\%; kandungan anti oksidan 45,95\% (pada konsentrasi bahan $2000 \mathrm{ppm}$ ); nilai toksisitas 1719,86 $\left(\mathrm{LC}_{50}\right)$; dan kandungan lovastain sebesar $79 \mathrm{ppm}$.

\section{DAFTAR PUSTAKA}

AOAC. 2005. Official Methods of Analysis, Association of the Official Analytical Chemist, Inc. Arlington. Virginia.

Anggraini, T. 2013. The Exotic Plants of Indonesia: Mahkota Dewa (Phaleria macrocarpa),Sikaduduak (Melastoma malabathricum Linn) and Mengkudu (Morinda citrifolia) as Potent Antioxidant Sources. Progress report. Daikin University - Andalas University. The Australian Indonesian Research Institute for Humanity and Development

Asben, A., Irawadi, T. T., Syamsu, K., Haska, N. 2012. Kajian Potensi dan Pemanfaatan Limbah Ampas Sagu Setelah Pretreatment. LUMBUNG / jurnal Penelitian Politeknik Pertanian Negeri Payakumbuh 11 (1)

Asben, A dan A. Kasim 2015. Studi Lama Fermentasi dan Tingkat Kadar Air dalam Produksi Pigmen Angkak Pada Substrat Ampas Sagu-Tepung Beras Menggunakan Monascus purpureus. Prosiding. Seminar Agroindustri dan Lokakarya Nasional Forum Komunikasi Pendidikan Tinggi-Teknologi Pertanian Indonesia (FKPT-TPI). Surabaya 2-3 September 2015. Prodi Teknologi Industri Pertanian Universitas Trunojoyo Madura.

Direktorat Gizi Depkes RI. 1996. Daftar Komposisi Bahan Makanan. Jakarta: Bhratara Karya Aksara. 
Hernindya, A., Swantara, M, D., Suaniti, N, M. 2014. Identifikasi Dan Uji Toksisitas Ekstrak Etanol Spons Hyrtios erecta Terhadap Larva Udang Artemia salina L. Indonsian E-Journal of Applied Chemistry 2 (1): 25-30.

Irdawati. 2010. Pengaruh Jumlah Starter Dan Waktu Fermentasi Terhadap Pigmen Yang dihasilkan Oleh Monascus purpureus Pada Limbah Ubi Kayu (Manihot utillisima). Esakta (1): 19-24.

Kasim, E., S. Astuti., dan N. Nurhidayat. 2005. Karakterisasi pigmen dan kadar lovastatin beberapa isolat Monascus purpureus. Biodiversitas 6 (4): 245-247

Kiat, L. J. 2006. Preparation and Characterization of Charboxymethil Sago waste Hidrogel. Master of Science University Putra Malaysia. Malaysia.

Kusumawati, T, H., Suranto., Styaningsih, R. 2005. Kajian Pembentukan Warna pada Monascus-Nata Kompleks dengan Menggunakan Kombinasi Ekstrak Beras, Ampas Tahu dan Dedak Padi sebagai Media. Biodiversitas Vol. 6 No. 3: 160-163

Lotong, N. and Suwanarit,P. 1990. Fermentation of angkak in plastic bags and regulation of pigmentation byinitial moisture content. J. Appl. Bacteriol. 68: 565-70.

Ma, J., Y. Li, Q. Ye, J. Li, Y. Hua, D. Ju, D. Zhang, R. Cooper, and M. Chang., 2000. Constituents of red yeast rice, a traditional chinese food and medicine. Journal of Agricultural and Food Chemistry 48: 5220-5225.

Nufus, H. 2013. Pengaruh Konsentrasi Inokulum Monascus purpureus Terhadap Produksi Pigmen Pada Substrat Tepung Biji Durian (Durio zibethinus). [Skripsi]. Bandung: Fakultas Pendidikan Matematika Dan Ilmu Pengetahuan Alam. Universitas Pendidikan Indonesia. 59 hal.

Su, Y.-C., Wang, J.-J., Lin, T.-T., and Pan, T.-M. 2003. Production of the secondary metabolites yaminobutyric acid and monacolin K by Monascus. J. Ind. Microbiol. Biotechnol. 30: 41-46.

Timotius, K, H. 2004. Produksi Pigmen Angkak oleh Monascus. Jurnal Teknik dan Industri Pangan Vol 15 (1): $79-85$.

Uhi, H, T. 2007. Peningkatan Nilai Nutrisi Ampas Sagu (Metroxylon Sp) Melalui Bio-Fermentasi. Jurnal Ilmu Ternak Vol. 7 (1): 26-31.

Yongsmith, B., 1999. Fermentative microbiology of vitamins and pigments, 1st Edn., Kasetsart University Press, Bangkok. 